\title{
Analysis of superheater tubes failure
}

\author{
Eukasz Felkowski ${ }^{1, *}$, Jakub Mędrala ${ }^{2}$ \\ ${ }^{1}$ Sumitomo SHI FW Energia Polska, Stress Department S.Staszica 31, 41-200 Sosnowiec \\ ${ }^{2}$ Sumitomo SHI FW Energia Polska, Boiler Engineering and Layout Department S.Staszica 31, 41-200 Sosnowiec
}

\begin{abstract}
Failures of boiler pressure parts, which working in high temperature and pressure conditions are often caused by overheating or corrosion. These two parameters are decisive, but not the only ones. Local stress concentration also depends on the type of headers support and external loads from pipelines. Boiler pressure parts subjected to all loads mentioned before are steam superheaters. Thermal expansion, high pressure and temperature lead to shortening superheaters lifetime. In the places with significant stress caused by all load combinations it is difficult to predict creep strains and material structure changes. This paper shows superheater in which considering external loads from pipeline and their influence on the stress concentration in the superheater tubes. This article also shows steel S304H creep analysis for $100 \mathrm{k}$ [h] results and creep equation with experimental developed constants.
\end{abstract}

\section{INTRODUCTION}

Many boiler pressure part damages were caused by unpredictable working conditions, e.g. material overheating, corrosion and erosion. There are not only cracking and rupture causes. Most of boiler pressure parts work in predictable conditions. Main design parameters determining pressure part durability are temperature and pressure. In the predictable cases, other loads were omitted. Examples of these are additional loads from piping, unbalance loads caused by mistakes during maintenance, simplifications during the design process [2]. Effect of those loads often causes local concentration of stress. Boiler elements subjected to the all combination are just steam superheaters [3]. These elements of boiler are characterized by work in high pressure and temperature parameters. In addition, they are subjected to external loads from pipelines, which affect their lifetime shortening. One of the most weakened part of superheaters are coil tubes.

In those tubes it is very hard to predict strain value due to creep phenomenon, and to predict changes in the material structure and lifetime [3].

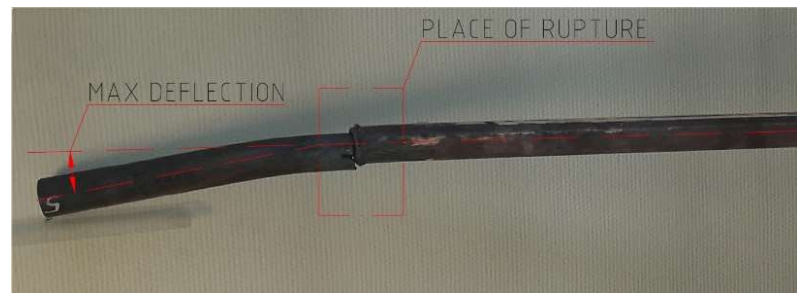

Fig. 1 Superheater tube rupture

Exemplary damage coil was shown in figure 1. Tubes rupture occurred in the place of crossing closure plate of superheater chamber. Tubes in the outside of chamber show significant deflections.

Due to the influence of external forces on the work of superheater tubes, it is necessary at the design stage to take into account all additional loads that may cause creeping intensification. Also during operation, pipeline working conditions should be examined to avoid any other tensions in superheaters area. Neglecting these works can cause additional loads in coils and headers, often larger than in design phase.

In this paper it will be shown analysis of the pipeline system affecting the superheater, influence of external forces on stress concentration in superheater tubes and creep analysis results for material S304H after 100,000h working time. Also for this purpose, the paper will propose a creep equation whose constants have been determined experimentally [3].

\footnotetext{
* Corresponding author: lukasz.felkowski@shi-g.com
} 


\section{ANALYZED SYSTEM DESCRIPTION}

The analyzed superheater is exposed to loads from outlet pipeline supplying steam to the turbine. For analysis purposes, a part of pipeline (with boundary conditions) with the biggest impact on the loads on the outlet header of superheater has been taken into account.

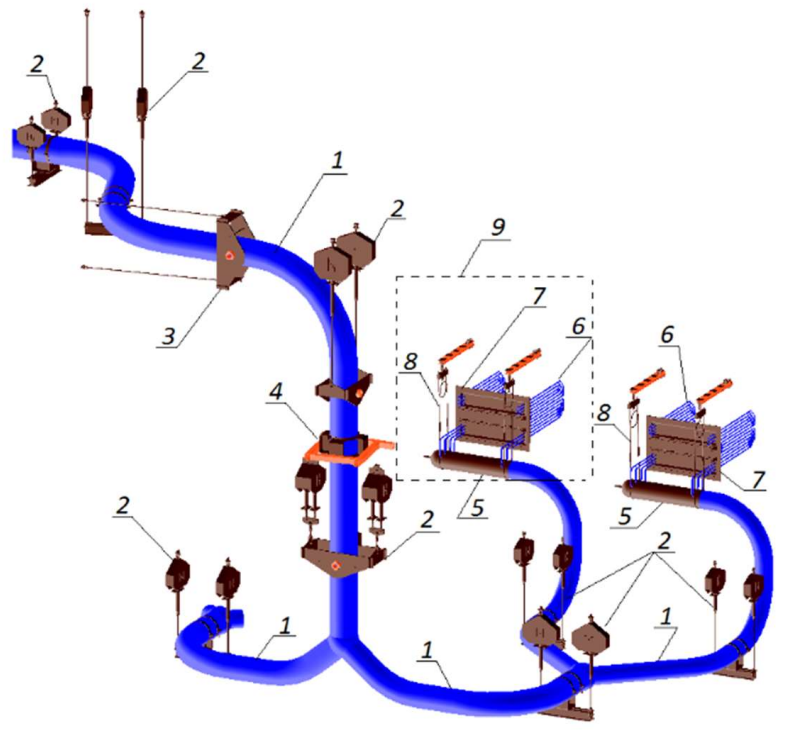

Fig. 2 The analyzed pipeline system affecting the superheater chamber

The system subjected to analysis is shown in Fig. 2 and consists of steam pipeline - pos. 1, supported with constant hanger pos. 2 , damper pos. 3 , the horizontal position is limited by guidance pos. 4 . Pipeline pos. 1 is connected to superheater outlet header pos. 5. Header is connected to coils pos. 6, coil tubes pass through thin steel closure plate pos. 7. Header weight is supported on suspensions pos. 8. The analyzed superheater was marked as pos. 9 .

Superheater header is shown in Fig. 3. Nozzles $Ø 51 \times 11$ pos. 1 are welded to the header $\varnothing 406 \times 100$ pos. 2. On the other end nozzles pos. 1 pass through thin steel plate pos. 3. Tubes are welded to plate by means of sealing weld.

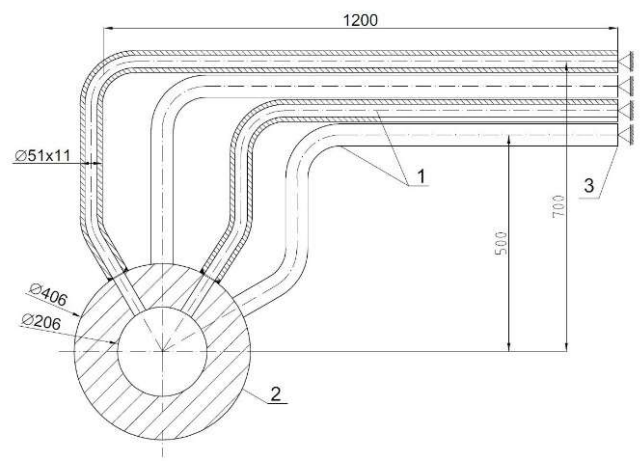

Fig. 3 The analyzed steam superheater header with nozzles

\section{STEEL S304H MATERIAL PROPERTIES}

Steel 18Cr-9Ni-3Cu-Nb-N (according ASME SA-213), X10-Cr-Ni-Cu-Nb-18-9-3 (according VdTUV 550) also known as $\mathrm{S} 304 \mathrm{H}$ is the material for steam superheater due to its good strength properties [4]. Chemical composition is shown in tab. 1. The use of this material for the superheater tubes affects the possibility of loading them with high temperature and pressure. Creep strength is one of the parameters that affects the trouble-free operation of superheaters. 
Table 1. Chemical composition of S304H steel.

\begin{tabular}{|c|c|c|c|c|c|c|c|c|c|c|c|}
\hline C & $\mathrm{Si}$ & $\mathrm{Mn}$ & $P$ & S & $\mathrm{Cu}$ & $\mathrm{Cr}$ & $\mathrm{Ni}$ & $\mathrm{Nb}$ & B & $\mathrm{N}$ & $\mathrm{Al}$ \\
\hline $\begin{array}{c}0.07- \\
0.13\end{array}$ & $\begin{array}{l}\text { Max } \\
0.30\end{array}$ & $\begin{array}{c}\operatorname{Max} \\
1.00\end{array}$ & $\begin{array}{c}\text { Max } \\
0.004\end{array}$ & $\begin{array}{c}\text { Max } \\
0.001\end{array}$ & $\begin{array}{l}2.5- \\
3.5\end{array}$ & $\begin{array}{l}17.0- \\
19.0\end{array}$ & $\begin{array}{l}7.5- \\
10.5\end{array}$ & $\begin{array}{c}0.3- \\
0.6\end{array}$ & $\begin{array}{c}0.0001- \\
0.0010\end{array}$ & $\begin{array}{c}0.05- \\
0.12\end{array}$ & $\begin{array}{c}0.0003- \\
0.0030\end{array}$ \\
\hline
\end{tabular}

Steel $\mathrm{S} 304 \mathrm{H}$ properties for ambient temperature $\left(20\left[{ }^{\circ} \mathrm{C}\right]\right)[5]$ :

- Yield Tensile Strength: 270 [MPa]

- Tensile strength: $590[\mathrm{MPa}]$

- Modulus of elasticity: 189000 [MPa].

Steel S304H properties for temperature $\left(650\left[{ }^{\circ} \mathrm{C}\right]\right)[5]$ :

- Yield Tensile Strength: $160[\mathrm{MPa}]$

- Tensile strength: $370[\mathrm{MPa}]$

- Modulus of elasticity: 137500 [MPa]

- Thermal expansion coefficient: $18,5 \mathrm{e}-6[1 / \mathrm{K}]$

- Creep resistance for $100000 \mathrm{~h}, S_{R T t}=116,0[\mathrm{MPa}]$

\section{BOUNDARY CONDITIONS AND LOADS}

The global analysis was performed in the AutoPipe software [6], including pipelines and suspension with the greatest impact on the forces at the point of connection with superheater header. This kind of software uses 1D finite elements. This approach allows quick model verification and identification of the most loaded parts of the superheater.

Fig. 4 shows the pipeline model created in the Auto Pipe software along with the analyzed superheater marked as pos.1. Pipeline pos. 2 is connected to superheater header - pos. 3 in point A. Combination of constant hanger suspension pos. 4 allows transferring the unchanged load in the specified displacement range. Guidance pos. 5 and 6 is responsible for limiting horizontal displacement of the pipeline pos. 2. Points B and $\mathrm{C}$ were defined with relevant boundary conditions in the form of displacements, which correspond to the operation of the pipeline during boiler operation.

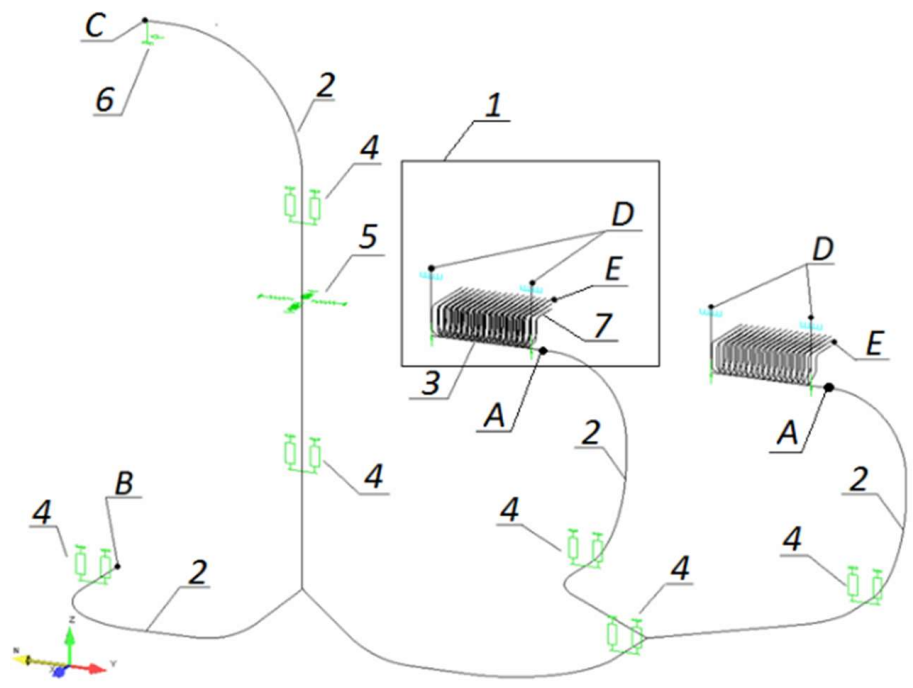

Fig. 4 Model of the analyzed system in the Auto Pipe software

The superheater header pos. 3 and the tubes pos. 7 are subjected to internal pressure $\mathrm{P}=24[\mathrm{MPa}]$ and temperature $\mathrm{T}=650\left[{ }^{\circ} \mathrm{C}\right]$. In the place where the suspensions of the superheater headers are fixed (point $\mathrm{D}$ ), the same conditions as for case B and C are taken into account. Superheater tubes pos. 7 at point E pass through the closure plate. The spherical boundary conditions have been assumed here, taking into account relevant displacements corresponding to the boiler operation. 


\section{STEAM SUPERHEATER ANALYSIS}

In the first stage of the analysis, a standard approach to the calculation of cylindrical elements (such as superheater tubes) subjected only to internal pressure was taken into account. In accordance with the requirements of standards EN 12952-3 [7] and EN 13480-3 [8], the basic calculations are limited to the dimensioning of tubes due to the circumferential stresses due to pressure.

The hoop stresses for the $\varnothing 51 \times 11$ coil can be calculated from the converted formula on the maximum pressure in the cylindrical body (1) according to EN 12952-3 or EN 13480 - 3:

$$
\sigma_{\theta}=\frac{P \cdot D_{m}}{2 \cdot e}
$$

$\sigma_{\Theta}$ - hoop stress, $P$ - internal pressure, $D_{m}$ - tube diameter, $e$ - tube thickness.

Hoop stress in pipe equals $\sigma_{\theta}=44$ [MPa]. Creep resistance equals $S_{R T t}=116,0[\mathrm{MPa}]$ what mean that the thickness of the tube was selected correctly due to the assumed pressure load. These calculations do not take into account additional loads from pipeline.

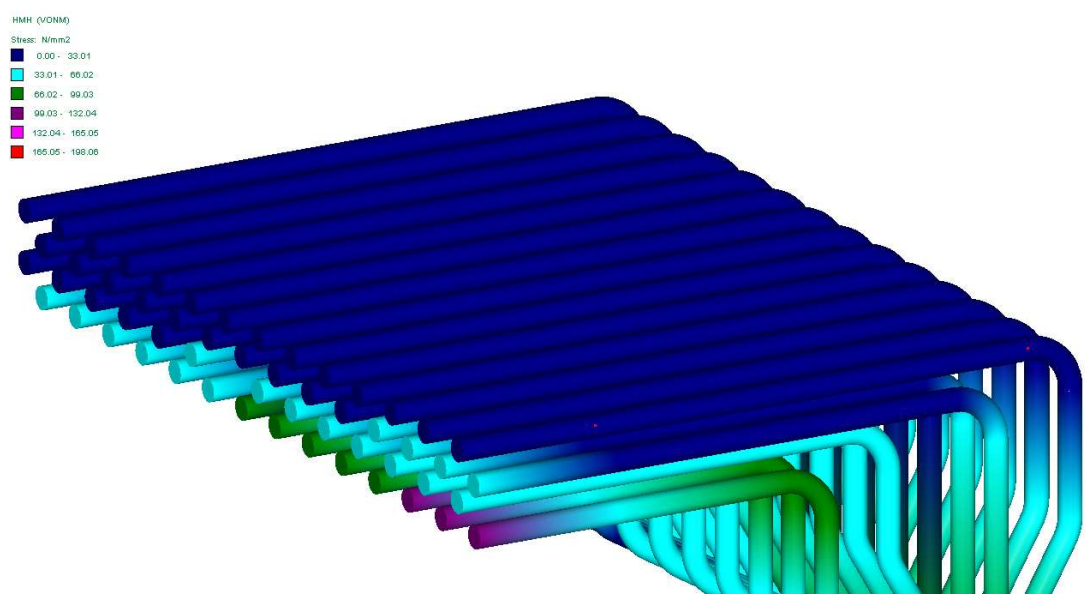

Fig. 5 Equivalent stress for adjusted pipeline suspensions. Max. tension $\sigma_{\mathrm{HMH}}=147 \mathrm{MPa}$

In the second stage of the analysis, the work of pipelines with optimal settings of the constant hanger suspensions was taken into account. This calculations were also made in the Auto Pipe software. The results of these analyses showed that the most stressed elements for working conditions are the superheater tubes in close area of closure plate. Fig. 5 shows the equivalent stresses for the described operating state.

The maximum reduced stresses in tubes are $\sigma_{H M H}=147[\mathrm{MPa}]$ and are lower than the yield stress $\operatorname{Re}_{650}=160 \mathrm{MPa}$. This means that the strain of the tubes is at the level of $92 \%$ for the elastic state.

Taking into consideration the long boiler operation time and creep of the S304H material, in steam superheaters, there may be significant strains of the tubes, which consequently excludes the superheater from further work. The value of equivalent stresses is higher than the creep strength for 100,000 [h], therefore it requires further analysis using the ANSYS software [9] using the proposed creep equation (2) [3, 10, 11, 12]:

$$
\varepsilon^{c}(t)=A\left(1-\exp \left(-\frac{t}{t_{I I}}\right)\right)+\exp \left(c_{3} \sigma-c_{4}\right) t+M\left\{\exp \left(-\left(\frac{0,5 t}{\exp \left(c_{1}+c_{2} \ln (\sigma+1)^{2}\right.}\right)^{-K}\right)\right\}
$$

$A$ - the greatest strains at the end of the first creep stage [\%], $t_{I I}-$ the start time of the second creep stage [h], $c_{1}, c_{2}-$ experimental constants, $c_{3}-$ the direction coefficient for the second creep stage, $c_{4}-$ the equation coefficient for the second creep stage, $K, M$ - coefficients describing the intensity of the destruction process, $\sigma-$ hoop stress [MPa], $\varepsilon^{c}(t)$ - actual creep strain [-], t-time [h]. Constants $A, t_{I I}, c_{1}, c_{2}, c_{3}, c_{4}, M$ and $K$ were determined experimentally at $650\left[{ }^{\circ} \mathrm{C}\right]$. 


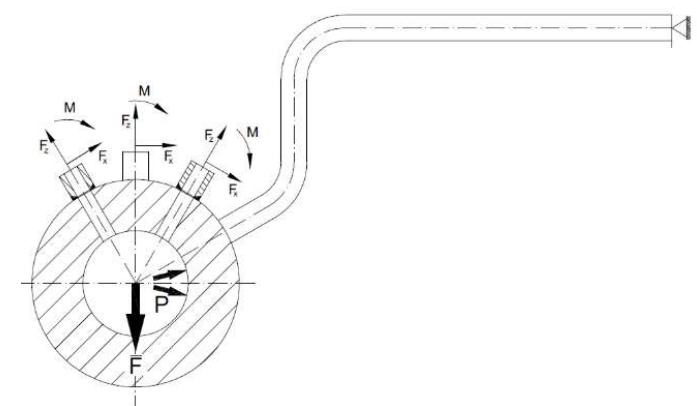

Fig. 6 Boundary conditions for submodel ANSYS software: forces $F_{x}, F_{z}$, moment $M$ and force $F$ obtained from analyzes in the Auto Pipe software

The Solid 185 type finite elements were used to build the model in the ANSYS software. The preliminary analysis in the ANSYS software was based on a typical solution for the theory of elasticity. Due to the narrow scope of analyses (only one tube with the greatest strain), the submodelling technique [13] was used to build the model, in which boundary conditions were assumed in the form of reaction obtained from analyses in the Auto Pipe software as in Fig. 6.

The results of the analyzes for the time $t_{0}=0[\mathrm{~h}]$ are shown in Fig. 7 and Fig. 8. The maximum equivalent stress is $\sigma_{0}=151,8[\mathrm{MPa}]$ and do not exceed the yield point $\operatorname{Re}_{650}=160[\mathrm{MPa}]$. It is higher than hoop stress by approx. 71 [\%]. The greatest equivalent strains are $\varepsilon_{0}=0,071[\%]$.
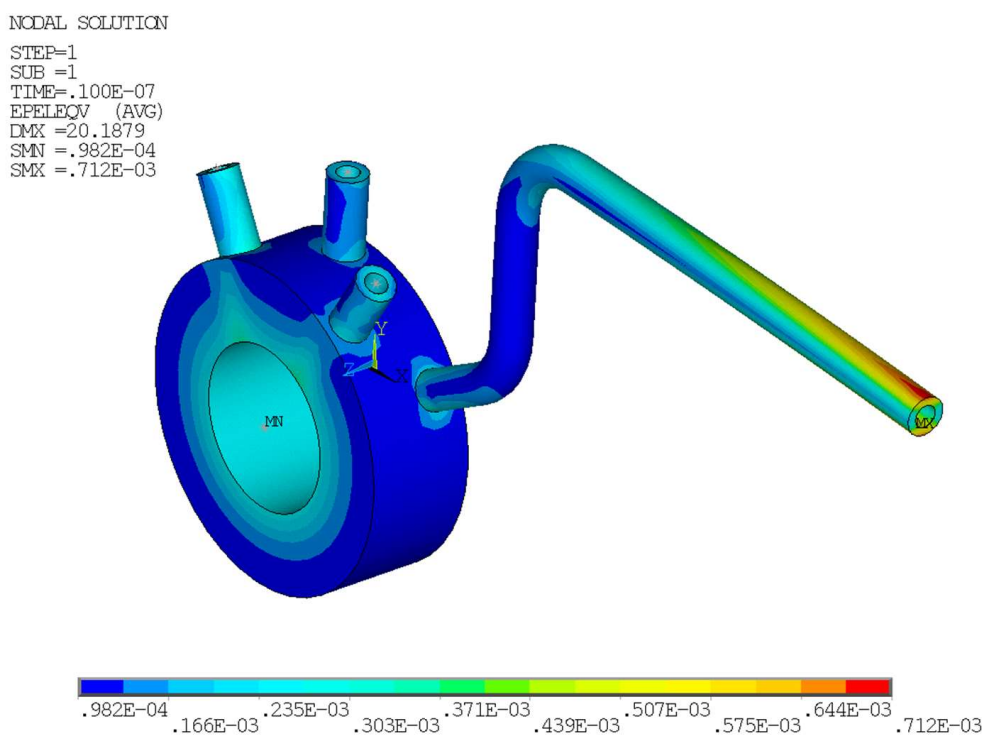

Fig. 7 Equivalent strains for $t_{0}=0[\mathrm{~h}]$ 


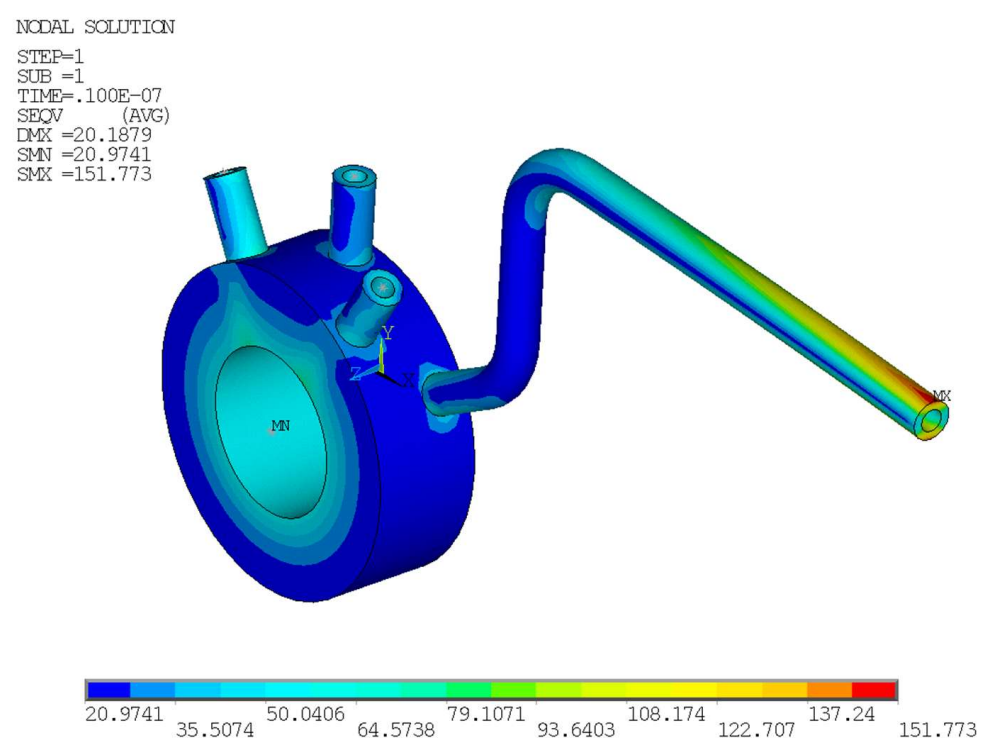

Fig.8 Equivalent stress for $t_{0}=0[\mathrm{~h}]$

For the expected lifetime $t_{l}=100000[\mathrm{~h}]$ the results are shown in Fig.9 and Fig.10. The largest creep deformations for $t_{1}$ are $\varepsilon_{l}=2,17$ [\%]. The reduced HMH stress is $\sigma_{l}=108,3[\mathrm{MPa}]$.

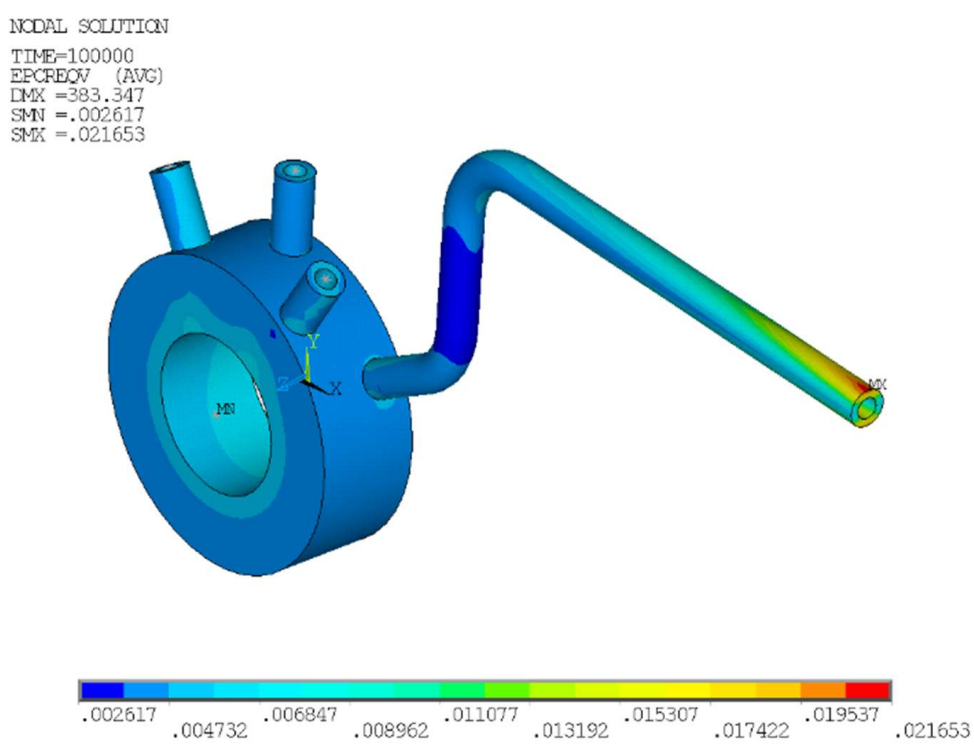

Fig. 9 Equivalent strains for $t_{I}=100000[\mathrm{~h}]$ 

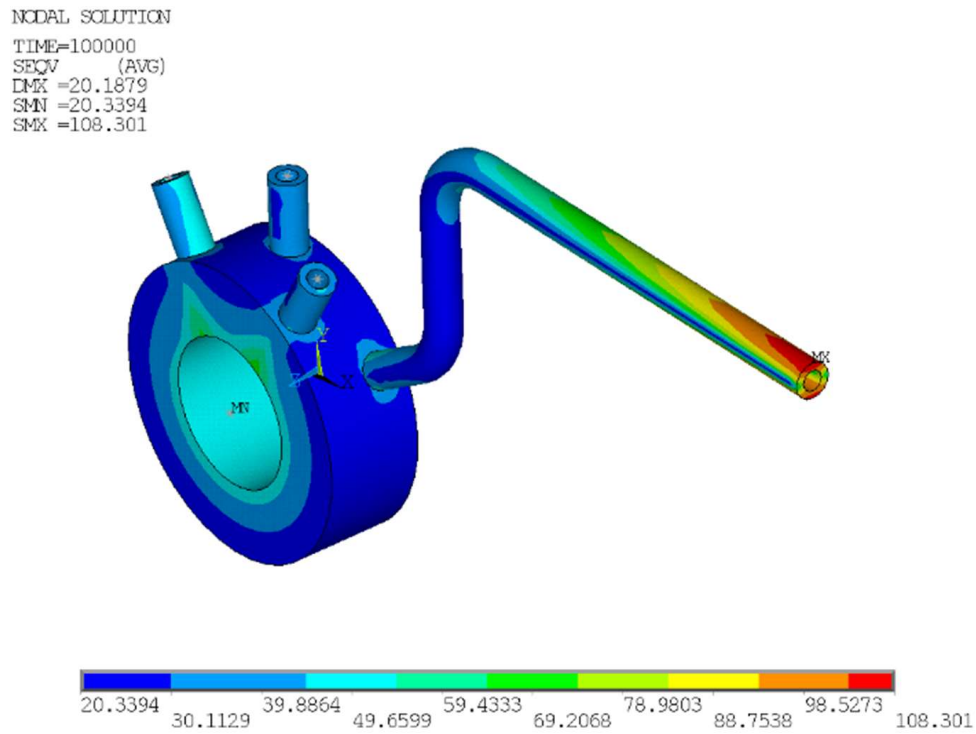

Fig. 10 Equivalent stress for $t_{1}=100000[\mathrm{~h}]$

The creep curve $\varepsilon(\mathrm{t})$ in Fig. 11 is shown for the place with the highest stress concentration (in the place, where tube pass through the closure plate).

For time $t_{1}=100000[\mathrm{~h}]$ stress has been relaxed by $29[\%]$ in relation to stresses for time $t_{0}$. In accordance with EN $13480-3$, assuming the safety factor $S_{f c r}=1,5$ the allowable stress $f_{c r}=77,33[\mathrm{MPa}]$ can be calculated. Because the stresses for time $t_{l}$ exceed $f_{c r}$, hence the conditions specified in EN 13480-3 are not met. Decreasing the coefficient value to 1.25 (in the case of monitored boiler operation time) is not possible due to exceeding the permissible deformation equal to $\varepsilon=1[\%]$. On the basis of the creeping diagram Fig. 11, the material achieves a deformation $\varepsilon=1$ [\%] after only $t_{1 \%}=$ 24177 [h], that is much earlier than the estimated lifetime $t_{1}=100000$ [h]. Regardless to the conditions laid down in EN 13480-3, it can be shown that the tube material at time $t_{l}$ is only in the second period of creep. It should also be noted that extended working time up to 200,000 [h] causes a rapid increase in the deformation speed, which indicates the third stage of creep.

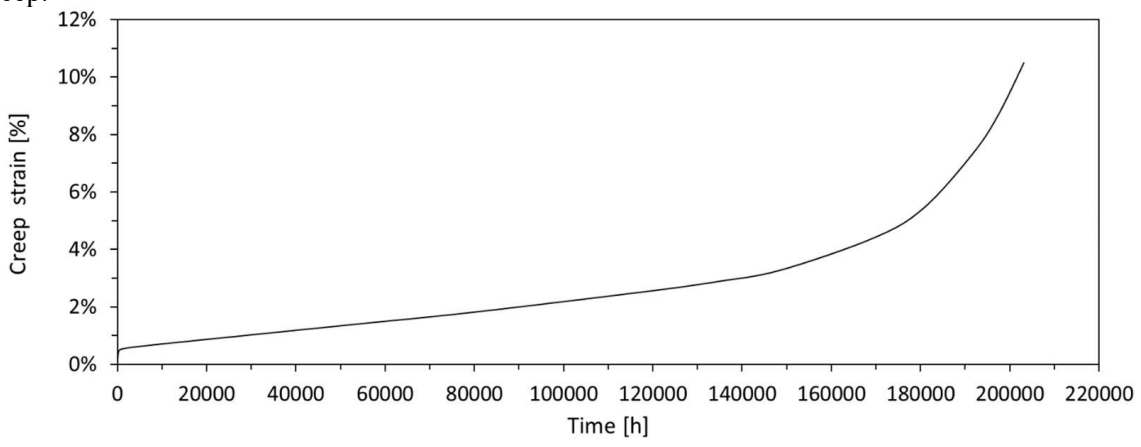

Fig.11 Creep curve $\varepsilon(t)$

\section{CONCLUSIONS}

The article presents the impact of the steam pipeline on the superheater, in which concentration of stress occurred in the tubes with high pressure and temperature. Performed analyses for the initial time showed that additional forces cause an increase in stresses by 71 [\%] in relation to the circumferential stresses calculated in accordance with EN 13480-3. It has also been shown that omitting additional loads in the analyses may result in incorrect estimation of the trouble-free operation of superheater. It has been shown that stresses for 100,000 [h] do not meet the requirements of EN 13480-3.

The paper presents a creep curve prepared on the basis of analyses using the proposed creep equation. The results of these analyses showed that the material S304H for time $t_{l}=100000[\mathrm{~h}]$ is in the second period of creep, and extending the service life to $200,000[\mathrm{~h}]$ may cause the destruction of the tubes due to entry into the third creep stage. 


\section{REFERENCES:}

1. P. Duda, Ł. Felkowski: An analysis of the steam superheater coil operation depending on different methods of coil support. Technical Transaction, pp. 187-192, (2017).

2. J. Sertić, D. Kozak, P. Konjatić, M. Kokanović: Analytical and numerical investigation of elastic-plastic behaviour of the connecting pipes between header and steam superheater. $\mathrm{w}$ Proceedings of the 6th International Congress of Croatian Society of Mechanics, Zagreb, (2009).

3. P. Duda, Ł. Felkowski: Analysis of superheater work under creep conditions. Acta Energetica, pp. 46-56, (2015).

4. T. Wala, A. Hernas: Dobor materiałow na przegrzewacze referencyjnego kotła nadkrytycznego. Prace IMiUE Politechniki Śląskiej 2009 t. III.

5. Material data for Super 304H.; Nippon Steel \& Sumitomo Metal.

6. $\quad$ Bentley Auto Pipe V8i Select series 10 Edition Workbook, (2016).

7. EN 12952-3: 2012, Część 3: Konstrukcja i obliczenia części ciśnieniowych kotła.

8. EN 13480-3: 2017, Część 3: Projektowanie i obliczenia rurociągów przemysłowych.

9. ANSYS User's Manual, Revision 19.1.

10. P. Duda, Ł. Felkowski, J. Dobrzański, H. Purzyńska, Modelling the strain and stress state under creep conditions in P91 steel. Materials at High Temperatures, Vol. 33, pp. 85-93, (2016).

11. P. Duda, Ł. Felkowski: An analysis of a y-pipe operation under creep condition. DYMAMESI 2017 : The International Colloquium Dynamics of Machines and Mechanical Systems with Interactions, Prague, (2017).

12. P. Osocha: Określenie stopnia uszkodzenia wysokociśnieniowych grubościennych elementów kotłów. PhD Thesis, (2009).

13. R. Miroshnik, Y. Shaked, D. Elmakis,: Life Assessment Evaluation of piping branch connection under creep \& fatigue. International Journal of Pressure Vessels and Piping, p. 147-154, (1997). 